\title{
INSTITUCIJE KAO DETERMINANTA EKONOMSKOG RASTA - PRIMJER HRVATSKE I ODABRANIH ČLANICA EU-A ${ }^{4,5}$
}

\section{SAŽETAK}

Ekonomski rast i njegovi uzroci dugo se istražuju u ekonomskoj znanosti. U novije vrijeme kvaliteta institucija prepoznata je kao važna determinanta ekonomskog rasta. Može se reći da je kvaliteta institucija gotovo neodvojiva od ekonomskog rasta suvremenih ekonomija. Koristeći pokazatelje institucijskog razvoja, autori istražuju jesu li i kako institucije djelovale na rast hrvatske ekonomije u usporedbi sodabranim članicama EU- $a^{6}$. Autori nalaze daje razvijenost institucija imala zapažen utjecaj na rast, u okviru koje se posebno analizira Indeks ekonomskih sloboda i Međunarodni indeks prava vlasništva. Upravo na tim područjima Hrvatska treba napraviti značajan institucijski pomak, odnosno potaknuti institucijsku promjenu. Pritom se ne smije zanemariti ni bitan utjecaj ostalih formalnih institucija, poput stupnja otvorenosti, vladavine prava, ali ni važnost poticanja promjene neformalnih institucija jer je značaj neformalnih institucija u Hrvatskoj relativno visok. Autori zaključuju da će poticanje institucijske promjene potaknuti i dovesti do pozitivnih procesa ekonomskog rasta.

Ključne riječi: ekonomski rast, institucije, institucijska promjena, Hrvatska, odabrane članice EU-a

1 Dr. sc., docent, Ekonomski fakultet u Rijeci, Sveučilište u Rijeci, Ivana Filipovića 4, 51000 Rijeka, Hrvatska.

E-mail: vesna.buterin@efri.hr

2 Dr. sc., docent, Ekonomski fakultet u Rijeci, Sveučilište u Rijeci, Ivana Filipovića 4, 51000 Rijeka, Hrvatska.

E-mail: bojana.olgic.drazenovic@efri.hr

3 Dr. sc., docent, Ekonomski fakultet u Rijeci, Sveučilište u Rijeci, Ivana Filipovića 4, 51000 Rijeka, Hrvatska.

E-mail: pavle.jakovac@efri.hr

4 Datum primitka rada: 15. 1. 2018.; datum prihvaćanja rada: 1. 3. 2018.

5 „Ovaj rad je financiran sredstvima Sveučilišta u Rijeci za projekt ZP UNIRI 3/17 (Razvoj i perspektive institucionalnih investitora u Republici Hrvatskoj)"

6 U okviru odabranih članica EU-a analizirat će se 10 tzv. novih članica EU-a, a to su: Češka, Slovačka, Mađarska, Poljska, Estonija, Latvija, Litva, Bugarska, Rumunjska i Slovenija 


\section{UVOD}

Jedna od najvažnijih tema političkog i ukupnog društvenog života u državi je pitanje ekonomskog rasta. Ekonomska znanost neprestano se bavi modelima ekonomskog rasta, kao i čimbenicima koji ga manje ili više pospješuju. U radu se analizira doprinos institucija, institucijskog okvira i institucijske promjene ekonomskom rastu. Teorija poznaje više vrsta institucija, kao i više mogućnosti njihova nastanka, razvoja i promjene. Često su neformalne institucije značajne barem koliko i formalne institucije, osobito kad se radi o bivšim tranzicijskim zemljama. Hoće li utjecaj institucija na gospodarski rast biti pozitivan ili negativan ovisi o nizu okolnosti, ali prvenstveno ovisi o njihovoj kvaliteti.

Nakon pregleda najvažnijih teorijskih spoznaja o institucijama u radu su prikazane relevantne značajke ekonomskog rasta u Hrvatskoj i odabranim članicama EU-a. Potom se temeljem znanstveno prihvaćenih pokazatelja kvalitete institucija analizira koje institucije najznačajnije djeluju na ekonomski rast u Hrvatskoj i odabranim članicama EU-a te se analiziraju načini njihovog djelovanja. Institucije imaju značajan utjecaj na stanje gospodarstva Hrvatske i odabranih članica EU-a, a institucijska promjena pokazuje se kao značajna determinanta ekonomskog rasta. Vrijeme gospodarskog uzleta stvara Hrvatskoj pogodno okruženje za institucijski rast, odnosno za poboljšanje kvalitete institucija i dostizanje razvoja kojeg imaju institucije u odabranim članicama EU-a.

\section{PREGLED LITERATURE}

Istraživanja koja proučavaju utjecaj institucijske razvijenosti i kvalitete institucija u posljednjih desetak godina doživjela su procvat, a neka od najznačajnijih prezentirana su u nastavku ovoga poglavlja. Većina se istraživanja utjecaja institucija na ekonomski rast i razvoj temelji na analizama vremenskih presjeka, što znači da su korišteni podatci mnogih zemalja za samo jedan period, iako taj period može biti i prosječni prosjek više godina. U posljednje vrijeme sve se češće koriste analize temeljene na vremenskim nizovima, prvenstveno kod analiziranja zemalja u razvoju zbog velike nestabilnosti njihovih stopa rasta u dužem vremenskom periodu (Pritchett, 1998: 23).

Istraživanja koja analiziraju utjecaj institucija na gospodarski rast potvrđuju da utjecaj postoji i da ga se može izmjeriti, no različiti su zaključci kada je u pitanju značaj tog utjecaja kao i čimbenici koji dovode do rasta institucija, a onda i do gospodarskog rasta. Većina autora, u nastavku, naglašava zaštitu vlasničkih prava, političke slobode, kvalitetnu i dobru vladu, razinu političke stabilnosti.

Barro (1991) je proveo prvo istraživanje uloge institucijske kvalitete u dugoročnom rastu na primjeru 98 zemalja u kojem je dokazao pozitivnu vezu institucijske kvalitete i ekonomskog rasta.

Usavršavanje pokazatelja dovelo je do uvođenja subjektivnih pokazatelja koje su u svojim istraživanjima uključili Mauro (1995) te Knack i Keefer (1995). Oni su kod ocjenjivanja institucija prvi uključili sljedeće pokazatelje: BERI - Business Environment Risk Intelligence, ICRG - International Country Risk Guide, te BI - Business International. Mauro je utvrdio statistički značajnu vezu institucija s investicijama i ekonomskim rastom, a Knack i Keefer pokazali su da rast i kvaliteta institucija dovodi do većih stopa rasta BDP-a. 
Chong i Calderon (2000) uočili su kauzalnost za koju su utvrdili da je dvosmjerna te da institucije potiču rast, ali i da rast dovodi do nastanka novih, boljih institucija. Autori su dokazali da je utjecaj institucija na ekonomski rast veći u siromašnim zemljama.

Istraživanje Rodrika, Subramaniana i Trebbia (2002) pokazalo je da značaj kvalitete institucija za gospodarski rast nadmašuje značaj zemljopisnog položaja i razine integracije zemlje. Pri tome su institucije mjerili vladavinom prava i zaštitom vlasničkih prava. Dokazali su veliku važnosti institucija za gospodarski rast.

Vrlo opsežno istraživanje Kaufmanna, Kraaya i Zoido-Lobatona (1999) provedeno je na preko 150 zemalja i pruža empirijske dokaze o snažnoj uzročnoj vezi između institucija i boljih ekonomskih rezultata. Promatrajući više od 300 pojedinačnih pokazatelja institucija sublimiranih u šest glavnih grupa zaključili su da bolje institucije dovode do boljih ekonomskih rezultata.

Vijayaraghavan i Ward (2001) istraživali su vezu institucijske infrastrukture i stopa ekonomskog rasta među 43 zemlje, došavši do zaključka da su za ekonomski rast najvažnije institucije zaštite vlasničkih prava i veličine vlade.

Bassanini, Scarpetta i Hemings (2001) su proučavajući gospodarski rast na primjeru OECD zemalja došli do zaključka da uloga institucija može biti pozitivna i negativna. Pozitivna jer na gospodarski rast djeluju inovacije, makroekonomsko okruženje, trgovinska otvorenost i razvijenost financijskih tržišta, a što je rezultat djelovanja dobrih institucija. Negativan je utjecaj kod loših institucija gdje stroga regulativa iadministrativna ograničenja na efikasnost tržišta rezultiraju negativnim utjecajem na ukupni gospodarski rast. Razlika u kvaliteti institucija utjecat će na razliku u gospodarskom rastu.

Roy i Tisdell (1998) zaključuju u svojim istraživanjima da su dobre institucije neophodne za održivi razvoj te da je vrlo bitna njihova implementacija i inkorporacija u društvo. Smatraju da se načini implementacije ne smiju usvajati i kopirati od drugih jer nešto što je uspješno u jednom društvu ili u jednom vremenu ne mora nužno biti uspješno u nekim drugim okolnostima.

Meon i Weill (2003) nalaze da su bolje institucije povezane s većom makroekonomskom učinkovitošću, a da najveći utjecaj imaju institucije vladavine prava i učinkovitosti vlada. Vladavina prava je institucija koja će u svakoj državi imati važan utjecaj na ekonomske rezultate i zato je treba poticati, ali svaka država treba razvijati svoj zakonodavni i institucijski okvir prilagođen specifičnoj situaciji, dostignutom stupnju razvoja i neformalnim institucijama koje u državi vladaju.

Takva razmišljanja potvrđuje istraživanje Davida i Macha (2006) koji su na primjeru Švicarske dokazali da je Švicarska razvojem svog puta, umjesto kopiranjem tuđeg puta institucijske promjene, postigla ekonomski uspjeh.

Ulubasoglu i Doucouliagos (2004) istražujući vezu institucija i ekonomskog rasta na modelu od 119 zemalja pronalaze da postoje značajni ukupni izravni i neizravni učinci političkih i ekonomskih sloboda na ekonomski rast. 
Acemoglu (2004) u svojim istraživanjima dokazuje da su razlike u ekonomskim institucijama temeljni razlog ekonomskog razvoja te razlikuje ekonomske i političke institucije. Ekonomske institucije u državi determiniraju inicijative i ograničenja za sve ekonomske aktivnosti te oblikuju ekonomske rezultate.

Udrugom istraživanjuAcemoglu(2005)istražujejesulipogrešneineodgovarajućemakroekonomske politike nekih zemalja (npr. visoka inflacija, velik proračunski deficiti i nerealni tečajevi) dovele do makroekonomskih nestabilnosti i sporog rasta ili je tome nešto drugo uzrok. On smatra da su zemlje s takvim makroekonomskim politikama imale slabe institucije. To uključuje i neučinkovitost po pitanju zaštite vlasničkih prava za investitore, koje je pogodovalo rasprostranjenosti korupcije i visokom stupnju političke nestabilnosti. Po njemu su pogrešne makroekonomske politike simptomi postojećih institucijskih problema, a ne glavni uzrok nestabilnosti. Prisutni institucijski problemi odražavaju se na gospodarstvo putem brojnih kanala, kako mikroekonomskih, tako i makroekonomskih. Prema tome, uzrok sporog rasta leži u institucijama, a makroekonomske politike koje ne dovode do rasta njihova su posljedica.

Algan i Cahuc (2010) naglašavaju važnost zakonodavnog okvira koji je ključan u razvoju i oblikovanju povoljnog institucijskog okruženja koje generira ekonomski rast.

Easterly (2013) ističe da je ekonomski rast uvijek i svugdje rezultat investicijske aktivnosti, a da je investiranje uvjetovano povoljnim uvjetima koje stvaraju razvijene institucije.

Goes (2015) povezuje institucijsku kvalitetu s razinom bruto domaćeg proizvoda po stanovniku i zaključuje da razvijenije države, odnosno one s višim razinama bruto domaćeg proizvoda po stanovniku, imaju razvijenije i kvalitetnije institucije od država koje imaju niže razine BDP-a po stanovniku.

Comin i Mestieri (2016) istražujući razloge vremenskog jaza kod usvajanja novih tehnologija između bogatih $\mathrm{i}$ siromašnih država dolaze do zaključka da države s visokorazvijenim institucijama, koje efikasno štite vlasnička prava, brže usvajaju nove tehnologije u svoje ekonomske sustave, koje u konačnici imaju dalekosežne učinke na dugoročni ekonomski rast.

lako su istraživanja o utjecaju institucijske razvijenosti na ekonomski rast brojna, autori se slažu u jednome, a to je da utjecaj institucija na ekonomski rast postoji.

\section{DINAMIKA KRETANJA BDP-A U HRVATSKOJ I ODABRANIM ČLANICAMA EU-A}

Kada se govori o stanju hrvatskoga gospodarstva danas, ne može se izbjeći rasprava o nedavnoj svjetskoj financijskoj krizi čiji su se učinci osjetili u svim zemljama, pa i u Hrvatskoj. Hrvatska je dugi niz godina ostvarivala negativne stope ekonomskog rasta, a zbog strukturnih problema oporavak gospodarstva bio je dugačak i otežan. $U$ grafikonu 1 prikazana je stopa rasta BDP-a po godinama.

\footnotetext{
(Acemoglu, Johnson i Robinson 2004); Radovi Darana Acemoglua dali su velik doprinos istraživanju institucija i njihovom doprinosu gospodarskom rastu i razvoju. Cf. također: (Acemoglu, Johnson i Robinson 2005:549-575) gdje autori istražuju izvore rasta u Europi od 1500. do 1850. godine
} 
Grafikon 1. Realne stope rasta hrvatskog bruto domaćeg proizvoda

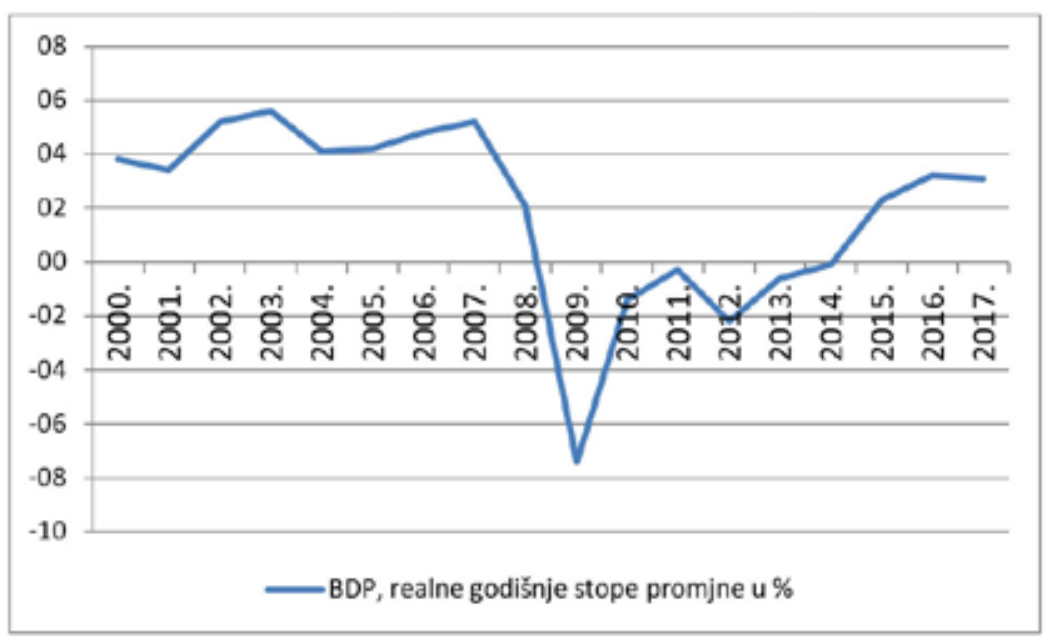

Izvor: obradili autori prema podatcima HNB-a, 2018.

Razdoblje od 2002. do 2007. godine karakterizira relativno stabilna stopa ekonomskog rasta koja se kretala između 4,2 i 5,5 \%. Taj je rast, međutim, bio generiran domaćom potražnjom koja je rasla zbog velike dostupnosti kredita, pa je rast bio financiran inozemnim zaduživanjem. Upravo u tome leže uzroci krize hrvatskog gospodarstva - u procikličkoj fiskalnoj i monetarnoj politici koja je omogućila takvu kreditnu ekspanziju i na tome temeljen ekonomski rast (IMF, 2011). Izbijanje svjetske financijske krize i nastanak kreditnih poremećaja u inozemstvu snažno su utjecali na uzroke rasta hrvatskog gospodarstva. Dok je vanjsko financiranje bilo lako dostupno, ono je djelovalo na odgađanje ekonomskih reformi, što se kasnije odrazilo na stope rasta (Vamvakidis 2007). Inozemno zaduživanje olakšavalo je troškove održavanja statusa quo, što je služilo zadržavanju iste procikličke ekonomske i monetarne politike u Hrvatskoj. Vanjsko zaduživanje djelovalo je kao sredstvo za otklanjanje pažnje s glavnih problema hrvatskog gospodarstva.

Nakon smanjivanja stope rasta 2008. godine na 2,1 \%, u 2009. godini promjena je bila negativna i iznosila je $-7,4 \%$. Sljedeće, 2010. godine, pad se nastavio s daljnjih -1,4\%. Godinu 2011. obilježio je daljnji pad od $-0,3 \%$. Pad se nastavio sve do 2014. godine. Činjenica da je u tom razdoblju pad uvoza bio veći od pada izvoza pridonijela je da negativna promjena ne bude još i veća.

Oporavak gospodarstva zabilježen je nakon šest godina, odnosno 2015. godine sa stopom rasta od 2,3 \% te se dalje nastavio i povećao u 2016. i 2017. godini. No, višegodišnja recesija ostavila je značajne posljedice u hrvatskom gospodarstvu, od stečaja i zatvaranja brojnih trgovačkih društava, promjena u gospodarskoj strukturi do pada broja zaposlenih osoba. Naime, istovremeno s padom stope ekonomskog rasta, primjetan je bio i pad broja zaposlenih te porast broja nezaposlenih osoba u Hrvatskoj, što je prikazano na grafikonu 2. 
Grafikon 2. Kretanje broja zaposlenih i nezaposlenih osoba u Republici Hrvatskoj

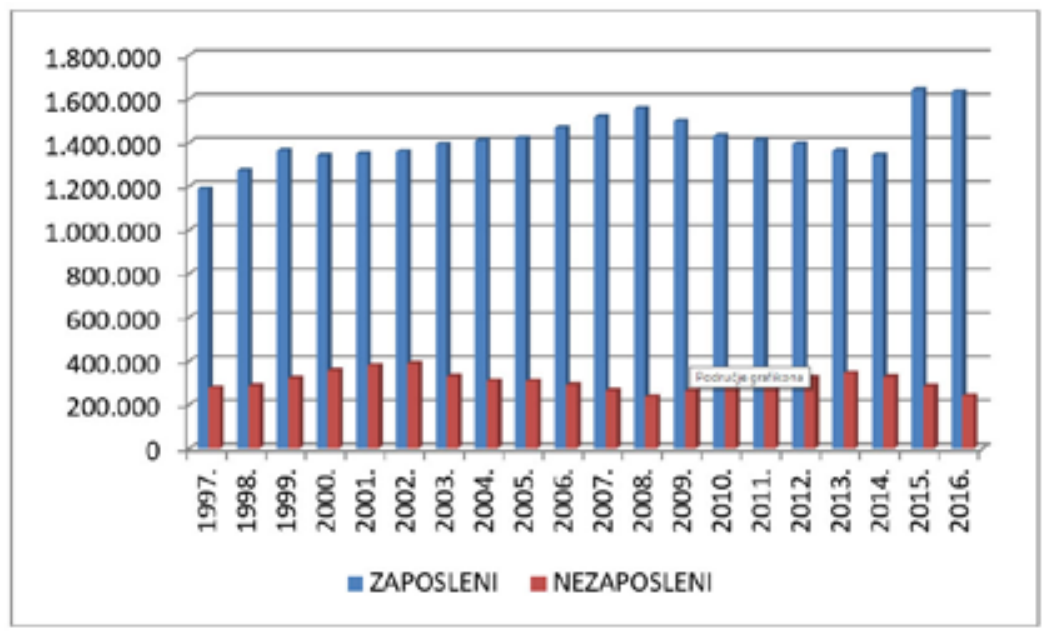

Izvor: obradili autori prema podatcima DZS-a i HZZ-a

Od 2002. do 2008. godine broj zaposlenih konstantno je rastao, a broj nezaposlenih opadao. Jednako tako stopa nezaposlenosti od 2002. godine stalno se smanjivala, pa je 2008. godine iznosila $13,2 \%$. Od 2009. godine do kraja 2015. godine prisutne su bile obratne pojave: broj zaposlenih se smanjivao, a broj nezaposlenih i stopa nezaposlenosti su se povećavale.

Do 2014. godine broj zaposlenih osoba pao je za 212.656 ili 13,7 \%, broj nezaposlenih osoba se povećao za 91.446 ili 38,6\% dok je stopa nezaposlenosti porasla s 13,2 na 19,6\%. Razlika između smanjenog broja zaposlenih osoba i povećanog broja nezaposlenih osoba iznosila je 121.210 osoba i to su bili ljudi koji su napustili tržište rada, putem odlaska u mirovinu ili na koji drugi način.

Već 2009. godine je izvješće Svjetske banke o konvergenciji Hrvatske s Europskom unijom predviđalo pogoršanje procesa realne konvergencije, dijelom zbog dotadašnjih temelja rasta, a dijelom zbog utjecaja krize u okruženju (The World Bank, 2009). Naime, domaća potražnja koja je bila glavni pokretač rasta u Hrvatskoj oslanjala se na veliku dostupnost i priljeve stranog kapitala. Budući da se zbog financijske krize, povećane odbojnosti prema riziku i smanjene međunarodne likvidnosti dostupnost inozemnog kapitala značajno smanjila, posljedice su se snažno osjetile na stopi rasta hrvatskog gospodarstva. Uz dosadašnji model rasta Hrvatska u razumnom vremenskom roku neće moći zatvoriti jaz dohotka i postići realnu konvergenciju s Europskom unijom. Velika prepreka ekonomskom rastu je niska stopa rasta izvoza koja je konstantno niža od zemalja u okruženju. Hrvatska stopa zaposlenosti među najnižim je stopama u EU-28, pa je doprinos radne snage ekonomskom rastu u Hrvatskoj nizak. Dosadašnji model ekonomskog rasta nije rezultirao značajnim kreiranjem radnih mjesta, odnosno značajnim povećanjem stope zaposlenosti.

Premda očuvanje sadašnje makroekonomske politike pridonosi nominalnoj konvergenciji, Hrvatska bi se s obzirom na situaciju u okruženju trebala preorijentirati na model rasta baziran na povećanju produktivnosti i na izvozu. 
Praksa je pokazala da gospodarstvo koje nije konkurentno ne može iskoristiti potencijalne koristi od pridruživanja Europskoj uniji (Fratzscher i Bussiere, 2004). S obzirom na krizu Eurozone 2011. i 2012. godine, pitanje odabira između nominalne i realne konvergencije postalo je sve više strateško pitanje hrvatske politike. „Kriza Eurozone bila je posljedica, između ostaloga, strukturnih problema Europske monetarne unije koji proizlaze iz neusklađenosti visokog stupnja monetarne integracije i niskog stupnja političke integracije" (Radošević 2012:128). U tablici 1 prikazane su godišnje stope rasta bruto domaćeg proizvoda odabranih tranzicijskih zemalja.

Tablica 1. Realne stope rasta bruto domaćeg proizvoda odabranih članica EU-a

\begin{tabular}{|cccccccccccc|}
\hline Država & $\mathbf{2 0 0 6 .}$ & $\mathbf{2 0 0 7 .}$ & $\mathbf{2 0 0 8 .}$ & $\mathbf{2 0 0 9}$ & $\mathbf{2 0 1 0 .}$ & $\mathbf{2 0 1 1}$ & $\mathbf{2 0 1 2}$. & $\mathbf{2 0 1 3 .}$ & $\mathbf{2 0 1 4}$ & $\mathbf{2 0 1 5 .}$ & $\mathbf{2 0 1 6 .}$ \\
Češka & 6,9 & 5,6 & 2,7 & $-4,8$ & 2,3 & 1,8 & $-0,8$ & $-0,5$ & 2,7 & 5,3 & 2,6 \\
Slovačka & 8,5 & 10,8 & 5,6 & $-5,4$ & 5,0 & 2,8 & 1,7 & 1,5 & 2,8 & 3,9 & 3,3 \\
Mađarska & 3,9 & 0,4 & 0,9 & $-6,6$ & 0,7 & 1,7 & $-1,6$ & 2,1 & 4,2 & 3,4 & 2,2 \\
Poljska & 6,2 & 7,0 & 4,2 & 2,8 & 3,6 & 5,0 & 1,6 & 1,4 & 3,3 & 3,8 & 2,9 \\
Estonija & 10,3 & 7,7 & $-5,4$ & $-14,7$ & 2,3 & 7,6 & 4,3 & 1,9 & 2,9 & 1,7 & 2,1 \\
Latvija & 11,9 & 10,0 & $-3,5$ & $-14,4$ & $-3,9$ & 6,4 & 4,0 & 2,6 & 1,9 & 2,8 & 2,1 \\
Litva & 7,4 & 11,1 & 2,6 & $-14,8$ & 1,6 & 6,0 & 3,8 & 3,5 & 3,5 & 2,0 & 2,3 \\
Bugarska & 6,9 & 7,3 & 6,0 & $-3,6$ & 1,3 & 1,9 & 0,0 & 0,9 & 1,3 & 3,6 & 3,9 \\
Rumunjska & 8,1 & 6,9 & 8,3 & $-5,9$ & $-2,8$ & 2,0 & 1,2 & 3,5 & 3,1 & 4,0 & 4,8 \\
Slovenija & 5,7 & 6,9 & 3,3 & $-7,8$ & 1,2 & 0,6 & $-2,7$ & $-1,1$ & 3,0 & 2,3 & 3,1 \\
Hrvatska & 4,8 & 5,2 & 2,1 & $-7,4$ & $-1,4$ & $-0,3$ & $-2,2$ & $-0,6$ & $-0,1$ & 2,3 & 3,2 \\
\hline
\end{tabular}

Izvor: izradili autori prema podatcima Eurostata, 2018.

Kod svih tranzicijskih zemalja u razdoblju od 2006. do 2016. ukupno je ostvaren rast, ali po bitno različitim stopama. Rast hrvatskog gospodarstva bio je po najnižoj stopi od svih promatranih zemalja. Prosječne stope rasta u razdoblju od 2006. do 2016. prikazane su grafikonom 3. 
Grafikon 3. Prosječne stope rasta u razdoblju od 2006. do 2016. godine

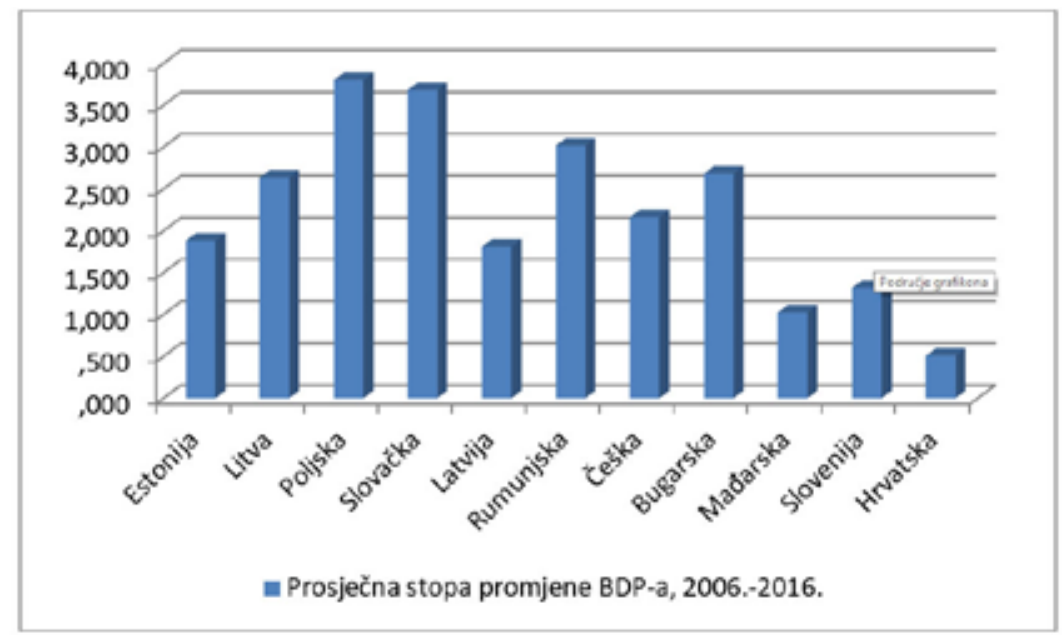

Izvor: izračunali i obradili autori prema podatcima Eurostata, 2018

U promatranom razdoblju hrvatsko gospodarstvo je najmanje raslo i to po prosječnoj stopi od $0,51 \%$ godišnje.

Hrvatskoj je potreban drugačiji model rasta, onaj koji će biti zasnovan na izvozu i investicijama u izvozni sektor i privlačenju izvozno orijentiranih stranih investicija.

Preduvjet za to je predvidljivost institucijskog okruženja i uspostavljanje sustava u kojem će transakcijski troškovi biti niski. To se postiže prisutnošću institucija koje podržavaju povoljno poslovno i društveno okruženje, odnosno institucija koje pridonose smanjenju nesigurnosti i snižavanju transakcijskih troškova. To se prvenstveno odnosi na odsustvo korupcije, vladavinu prava, zaštitu prava vlasništva i sigurnost provedbe ugovora, a postiže se institucijskom promjenom. $\mathrm{Na}$ taj način institucijska promjena postaje ne samo preduvjet bržeg ekonomskog rasta i razvoja Hrvatske nego i čimbenik brže realne i ukupne konvergencije Republike Hrvatske razvijenim državama Europske unije.

\section{INSTITUCIJSKA RAZVIJENOST KAO ČIMBENIK EKONOMSKOG RASTA U HRVATSKOJ I ODABRANIM ČLANICAMA EU-A}

Doprinos institucija i institucijske promjene koja bi pridonijela ekonomskom i ukupnom rastu Republike Hrvatske očekuje se prvenstveno od temeljnih institucija kao što su ustav ili vladavina prava. One su prve koje trebaju pridonositi političkoj stabilnosti, sprječavati korupciju, poboljšavati efikasnost javnog sektora i štititi prava vlasništva od protupravnog prisvajanja privatnih osoba ili vlade. Snažne institucije utječu na više razine dohotka po stanovniku jer oblikuju uvjete za investicije, tehnološki napredak i rast. Napredne ekonomije počivaju na snažnim institucijama kao što su vladavina prava, provedba ugovora i pravo vlasništva. Društva sa slabim ili lošim institucijama dugoročno sporije rastu, a u njima je prisutan i problem s kontinuiranim promjenama. 
Tamo gdje je korupcija i prisvajanje privatnog vlasniš̌tva uobičajeno, povrat na investicije je smanjen, a moguće i da ga uopće nema. Nepovoljno institucijsko okruženje u državi, misleći prvenstveno na nedostatak vladavine prava, odrazit će se na gospodarstvo pa će se tako razvijati one aktivnosti gdje opasnost od gubitka ili izvlaštenja donosi najmanje štete. U takvim društvima razvijaju se aktivnosti koje su radno intenzivne, dok su kapitalom i znanjem intenzivna poduzeća u najvećoj mjeri u domeni države i njezinih agenata.

Države sa sigurnim vlasničkim pravima bit će privlačnije za investiranje u fizički kapital i u ljudske potencijale od onih gdje su ta prava nejasna ili nedovoljno zaštićena. Fizički kapital i ljudski potencijali učinkovitije će se koristiti tamo gdje je vlasništvo sigurno. Sigurnost da će država štititi i stajati iza svakog oblika vlasništva i da država zbog raznih razloga, poput pada proračunskih prihoda, pritisaka javnosti, promjena u vladi ili promjena u vladinim društvenim i ekonomskim prioritetima i slično neće odbacivati ili ne priznavati ugovore, povećava sigurnost, smanjuje rizike i snižava transakcijske troškove. Također, za privlačenje kapitala i za ekonomski rast bitno je da ne postoji rizik od izvlašćivanja ili prisilne nacionalizacije.

Jedan od mogućih načina mjerenja razine zaštite prava vlasništva je Međunarodni indeks prava vlasništva - IPRI - International Property Rights Index.IPRI je kompozitni indeks koji uspoređuje 127 država u razini zaštite vlasništva, fizičkog i intelektualnog. Analize se rade istražujući zakonodavni i politički okvir te analizirajući provođenje i primjenu zakona. Premda se radi o objektivnom indeksu kojem su izvor podatci Svjetska banka, Svjetski gospodarski forum te druge međunarodne organizacije, indeks ne može u sebi sadržavati specifične karakteristike koje se odnose na svaku pojedinu državu. Najveća moguća vrijednost indeksa je 10,0 koja označava najjaču razinu zaštite vlasničkih prava, a najmanja 0,0 što bi značilo da u toj zemlji uopće ne postoji zaštita prava vlasništva. Na grafikonu 4 prikazan je rang zemalja prema IPRI pokazatelju.

Grafikon 4. Izabrane države prema IPRI pokazatelju za 2017. godinu

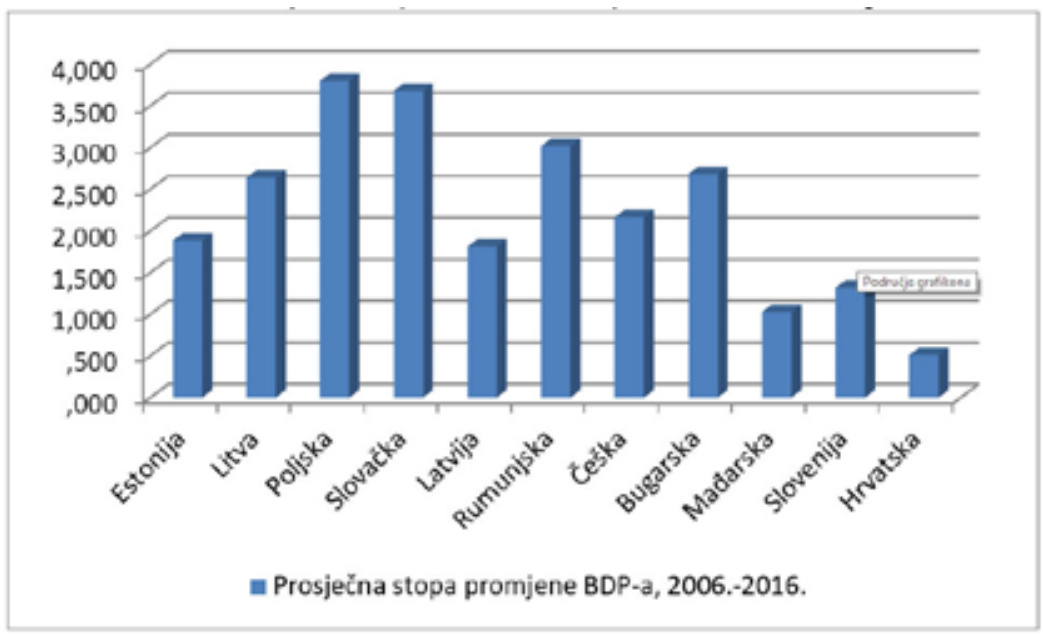

Izvor: obradili autori prema International Property Rights Index, 2018. 
Premda niti u jednoj zemlji indeks nema vrijednost 10, primjetno je da su zemlje u kojima je visoka razina zaštite prava vlasništva upravo bogate i visokorazvijene zemlje Europe i svijeta ${ }^{8}$. Tranzicijske zemlje ${ }^{9}$ koje predstavljaju tzv. nove članice EU-a te Hrvatska nalaze se u gornjoj polovici, što svjedoči da u njima postoje pozitivni institucijski pomaci premda i među njima ima bitnih razlika - Estonija i Češka su na 25. i 30. mjestu s vrijednošću IPRI indeksa 7,2 odnosno 6,9, a Hrvatska s vrijednošću indeksa od 4,8 je na 86. mjestu, odmah iza Bugarske. Na začelju su siromašne zemlje Afrike i Južne Amerike $^{10}$.

Učinak jačanja povjerenja u sustav zaštite vlasnišstva je suzbijanje neformalnog gospodarstva, učinkovitija alokacija resursa i jačanje investicijske aktivnosti. Izostanak bojazni od izvlaštenja, neizvjesnosti i nepredvidivih gubitaka imovine privlači pažnju domaćih investitora te mobilnog međunarodnog kapitala i tako djeluje na povećanje ekonomske učinkovitosti.

Gospodarski rast ne čine institucijske razlike same po sebi, nego su one uvjet i sredstvo od kojega država i stanovništvo može imati koristi, a rast dolazi tek kao posljedica i rezultat. Investicije se pojavljuju kao jedan od rezultata institucijskog razvoja. Danas je među tranzicijskim zemljama prisutan veliki jaz kvalitete institucija. Neke su zemlje postigle institucijsku kvalitetu koja je u nekim područjima veća i od one u razvijenim zemljama, a neke su i danas na institucijskom začelju. Već 2008. godine Latvija, Češka i Mađarska imale su bolje uvjete za poslovanje, mjereno Heritage Foundation indeksom ekonomskih sloboda, nego Francuska i Portugal, dok su iste godine Rusija, Bjelorusija i Turkmenistan bile na 136., 147. i 152. mjestu od 157 zemalja (Dang, 2009).

Rezultat institucijske reforme i institucijskog razvoja je porast investicija koje utječu na gospodarski rast. Proučavajući gospodarstva tranzicijskih zemalja u razdoblju od 1990. do 2007. Dang (2009) je dokazao da su institucijski faktori, kako ekonomski tako i politički, imali značajan utjecaj na privlačenje investicija, domaćih i stranih. K tome, uspješnost samog tranzicijskog procesa bila je snažno povezana s visinom investicija.

Heritage indeks ekonomskih sloboda je indikator kvalitete formalnih institucija a sublimira pokazatelje porezne politike, vladinih intervencija, trgovačke politike, monetarne politike, regulative novčanih tokova i stranih investicija, bankarske regulative, kontrole plaća i cijena, zaštite vlasničkih prava, učinkovitosti zakona i udjela paralelnog tržišta. Međutim, jedan problem Heritage pokazatelja je što i on usprkos velikoj bazi podataka i konzistentnoj metodologiji prikupljanja podataka podliježe dozi subjektivnosti. Drugi, možda i veći problem je što pokušava različite zemlje svesti na zajednički nazivnik, što nije uvijek ni lako ni moguće. Osim toga, ono što je za neku zemlju dobro i uobičajeno, za drugu može biti kontraproduktivno. Ipak, računajući da u institucijskom smislu među promatranim tranzicijskim zemljama ne postoje razlike kao što bi postojale među tim zemljama s jedne strane i zemljama, primjerice, afričkog ili američkog kontinenta s druge strane, Heritage indeks može se koristiti kao zajednička mjera institucijskog razvoja tranzicijskih zemalja prvenstveno zbog usporedivosti koja proizlazi iz konzistentne metodologije.

8 Prvih 11 mjesta na svjetskoj ljestvici zauzimaju: N. Zeland, Finska, Švedska, Švicarska, Norveška, Japan, Nizozemska i Kanada

9 Estonija zauzima 25. mjesto na svjetskoj ljestvici, Češka je na 30. mjestu, Slovačka je 37., Poljska se nalazi na 41. mjestu, Slovenija na 47. mjestu, Mađarska je 48., Litva je 50., Latvija je 63., Rumunjska je 73., Bugarska zauzima 85. mjesto, a najslabije rangirana u ovom skupu država je Hrvatska (86. mjesto)

10 Bangladeš je na 125. mjestu, Venezuela na 126. mjestu i Republika Jemen na 127. mjestu 
Uspoređujući Hrvatsku s ostalim odabranim članicama EU-a treba reći da su sve promatrane države ostvarile napredak u indeksu ekonomskih sloboda, međutim, taj napredak nije kod svih bio isti. Relativno najmanji napredak ostvarila je Češka, ali taj podatak može zavarati ako se ne uzme u obzir da je Češka već 1996. imala najveću razinu indeksa od svih promatranih država i da je to država koja i dalje ostaje pri vrhu odabranih članica EU-a. U tablici 2 prikazan je ostvareni napredak svih odabranih zemalja.

Tablica 2. Povećanje Heritage indeksa ekonomskih sloboda za Hrvatsku i odabrane članice EU-a

\begin{tabular}{|cccccc|}
\hline Redni broj & Država & $\mathbf{1 9 9 6 .}$ & $\mathbf{2 0 1 3 .}$ & $\mathbf{2 0 1 7 .}$ & $\begin{array}{c}\text { Indeks } \\
\mathbf{2 0 1 7 . / 1 9 9 6 .}\end{array}$ \\
1. & Češka & 68,1 & 70,9 & 74,2 & 108,9 \\
2. & Slovačka & 57,6 & 68,7 & 65,3 & 113,4 \\
3. & Mađarska & 56,8 & 67,3 & 66,7 & 117,4 \\
4. & Poljska & 57,8 & 66,0 & 68,5 & 118,5 \\
5. & Estonija & 65,4 & 75,3 & 78,8 & 120,5 \\
6. & Latvija & 55,0 & 66,5 & 73,6 & 133,8 \\
7. & Litva & 49,7 & 72,1 & 75,3 & 151,5 \\
8. & Bugarska & 48,6 & 65,0 & 68,3 & 140,5 \\
9. & Rumunjska & 46,2 & 65,1 & 69,4 & 150,2 \\
10. & Slovenija & 50,4 & 61,7 & 64,8 & 128,6 \\
11. & Hrvatska & 48,0 & 61,3 & 61,0 & 127,1 \\
\hline
\end{tabular}

Izvor: obradili i izračunali autori prema Index of Economic Freedom, 2018.

Godina 1996. prva je godina od koje postoje usporedivi podatci Heritage indeksa za sve odabrane države, pa je stoga uzeta kao početna godina. Zbog niske polazne osnove Rumunjska, Bugarska i Litva ostvarile su relativno najveći napredak u razvoju institucija. Na razvoj institucija u Bugarskoj i Rumunjskoj snažno je utjecao proces pridruživanja Europskoj uniji. Te su zemlje zajedno s Hrvatskom 1996. godine imale najlošije rezultate mjereno Heritage indeksom ekonomskih sloboda.

Hrvatska je imala vrlo loš početni položaj i uz nedovoljan napredak do 2017. godine ostala je najniže rangirana od odabranih članica EU-a. Napredak Hrvatske bio je primjetan u razdoblju od 2008. godine nadalje što se može povezati s jačom predanošću Hrvatske da dovrši proces pridruživanja EU-u. Daljni napredak Hrvatske u pogledu institucijske razvijenosti pridonio bi povoljnom investicijskom okruženju, a što bi u konačnici dovelo do viših stopa ekonomskog rasta.

Na grafikonu 5 prikazan je pojedinačni napredak svih odabranih članica EU-a. Niti jedna od promatranih država nije rangirana u razred potpuno slobodnih zemalja (Free) u koji spadaju one kod kojih je vrijednost indeksa preko 80 . Svega pet zemalja svijeta nalazi se u tom razredu i to redom: Hong Kong $(90,2)$, Singapur $(88,8)$, Novi Zeland $(84,2)$, Švicarska $(81,7)$ i Australija $(80,9)$ (Heritage Country Rankings, 2018). 
Razred uglavnom slobodnih zemalja (Mostly free) čine države kojih je vrijednost indeksa ekonomskih sloboda između 70,0 i 79,9, a tamo su 2017. godine spadale Češka, Estonija, Latvija i Litva. Sve ostale promatrane zemlje spadale su u razred umjereno slobodnih zemalja (Moderately free), s vrijednostima indeksa od 60,0 do 69,9. Treba napomenuti da u taj razred spadaju i neke od najrazvijenijih europskih zemalja, poput Belgije i Francuske.

Grafikon 5. Heritage indeks ekonomskih sloboda za odabrane članice EU-a od 1996. do 2017. godine

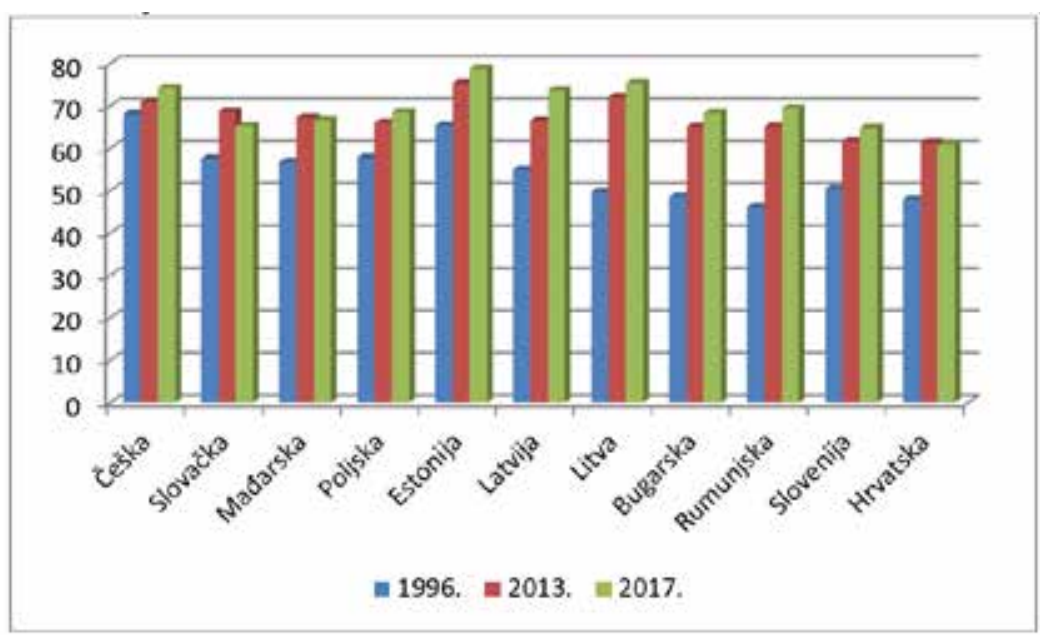

Izvor: izradili autori prema Index of Economic Freedom, 2018.

Godine 1996. samo su Češka i Estonija bile u razredu umjereno slobodnih zemalja dok su sve ostale zemlje bile lošije rangirane. Slovačka, Mađarska, Poljska, Latvija i Slovenija bile su u razredu uglavnom neslobodnih zemalja (Mostly unfree), a Litva, Bugarska, Rumunjska i Hrvatska bile su u razredu ugušenih ekonomskih sloboda (Repressed). U tom smislu kod svih je odabranih tranzicijskih zemalja vidljiv napredak u razvoju institucija. Napredak institucija odrazio se na privlačenje stranih investitora i na ulaganja koja su kroz tranzicijski period uslijedila. Zemlje s višom razinom institucijske razvijenosti brže su izašle iz recesije i imale su više stope gospodarskog rasta.

Budući da su sve odabrane zemlje bile pogođene gospodarskom krizom 2009. godine, na grafikonu 6 prikazane su prosječne stope promjene BDP-a od 2010. nadalje 
Grafikon 6. Prosječne stope rasta u razdoblju od 2010. do 2016. godine

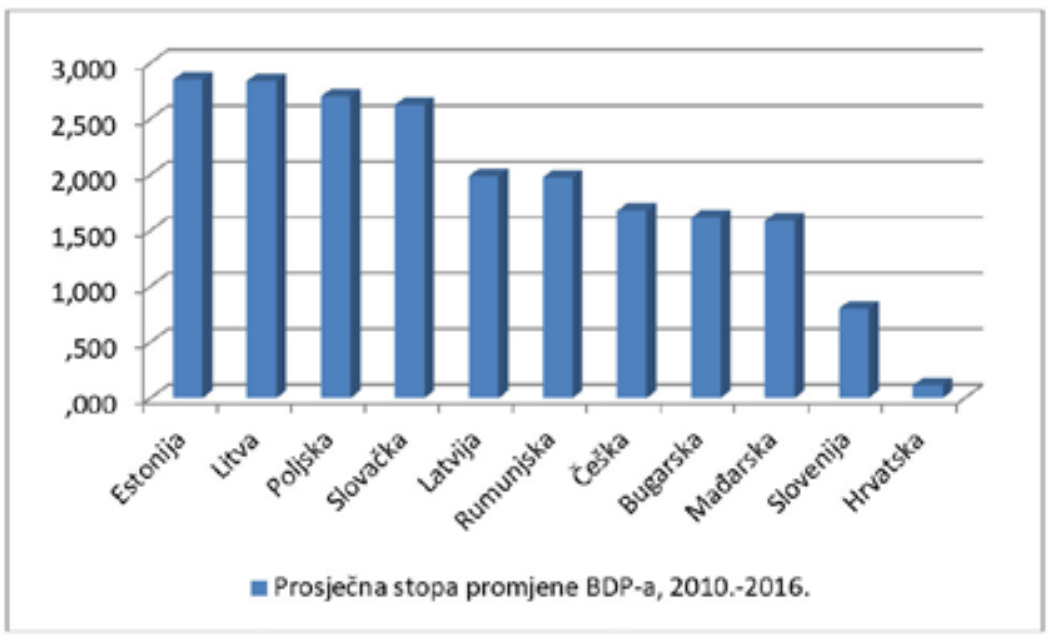

Izvor: izračunali i obradili autori prema podatcima Eurostata, 2018

U razdoblju od 2010. godine nadalje zemlje s većom institucijskom razvijenošću daleko brže su se oporavljale od Hrvatske. U tom razdoblju prosječan rast hrvatskog gospodarstva bio je po stopi od $0,11 \%$ godišnje, što je značajno ispod svih ostalih promatranih zemalja. Godišnje stope rasta hrvatskog gospodarstva u usporedbi s prosječnim godišnjim stopama ostalih promatranih zemalja prikazana je na grafikonu 7.

Grafikon 7. Godišnje stope rasta u razdoblju od 2006. do 2016. godine

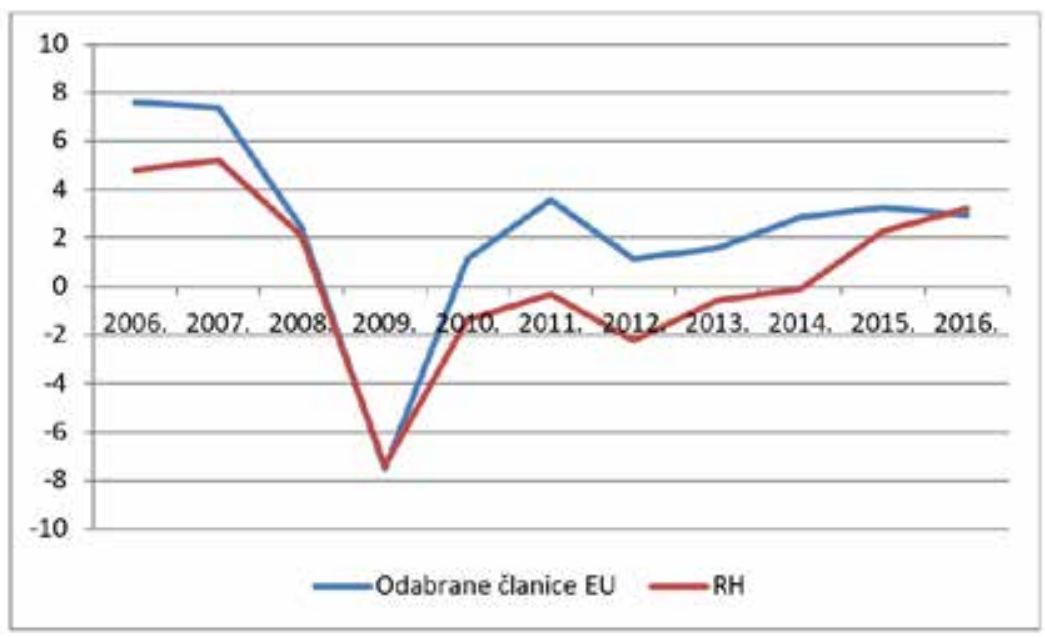

Izvor: izračunali i obradili autori prema podatcima Eurostata, 2018 
U svim promatranim zemljama, osim Poljske, 2009. godina bila je godina značajnog pada bruto domaćeg proizvoda, ali samo u Hrvatskoj je stopa bila negativna sve do 2015. godine. Od promatranih zemalja Hrvatska je zemlja s najlošijim pokazateljima institucijskog razvoja. Češka, Estonija, Latvija i Litva imale su brži gospodarski rast prije krize te brži gospodarski oporavak nakon izbijanja krize, što treba pripisati strukturi njihovog gospodarstva kao i njihovoj sveukupnoj makroekonomskoj situaciji. Ali povoljnost njihovog institucijskog okruženja, odnosno njihova institucijska razvijenost omogućila je uvjete povoljne za nastanak takve gospodarske strukture. Institucijsko okruženje svih promatranih zemalja reflektira se u njihovoj makroekonomskoj situaciji, odnosno u rastu i razvoju njihovih gospodarstava.

Dinamika institucijskog razvoja imala je utjecaj na ukupni rast i razvoj odabranih članica EU-a. Treba, međutim, reći da ono što vrijedi u Europskoj uniji, a vrijedilo je i za Češku, Mađarsku, Poljsku ili Sloveniju, ne mora nužno vrijediti za Hrvatsku ili za neku drugu državu. To proizlazi iz njihovog različitog stupnja razvoja i različite početne institucijske razine, osobito u pogledu neformalnih institucija. Svaka bi zemlja, pa tako i Hrvatska trebala tražiti svoj put institucijskog i ekonomskog rasta i razvoja, primjenjujući kod sebe ono što će sigurno imati pozitivan učinak, primjerice kontrolu korupcije, provedbu ugovora ili vladavinu prava, uz istovremeno dobro i pažljivo promišljanje oko usvajanja i primjene tuđih standarda.

\section{ZAKLJUČAK}

Dok se tematikom gospodarskog rasta ekonomska znanost bavi kroz vrlo dugo razdoblje, institucije su se u središtu interesa znanstvenika pojavile prije relativno kratkog vremena. No, i u tom relativno kratkom vremenu pruženo je nebrojeno dokaza o izravnom utjecaju institucija na ekonomski rast. Brojni se autori slažu da je kvaliteta institucija jedna od značajki gospodarskog rasta.

Analizirajući karakteristike gospodarskog rasta u Hrvatskoj i odabranim članicama EU-a može se zaključiti da je rast u Hrvatskoj bio temeljen na krivim pretpostavkama, odnosno da je najvećim dijelom temeljen na potrošnji koja je bila generirana visokim rastom vanjskog duga. Posljedice takve ekonomske politike jasno su se vidjele u vrijeme višegodišnjeg pada gospodarstva.

Uspoređujući institucijsku razvijenost Hrvatske i odabranih članica EU-a sa značajkama njihovog gospodarskog rasta, autori nalaze da postoji značajan prostor za poboljšanje kvalitete institucija u Hrvatskoj. Pomaci u razini zaštite vlasničkih prava, ali prvenstveno u općoj razini vladavine prava, dovest će do viših stopa gospodarskog rasta. Predvidivost sustava, odnosno postojanje jasnih i nedvosmislenih pravila koja jednako vrijede za sve sudionike u izravnoj su vezi s ekonomskim rastom. Institucije se pokazuju kao neizostavna determinanta ekonomskog rasta Hrvatske.

Autori posebno naglašavaju da Hrvatska pri implementaciji institucijske promjene mora biti vrlo oprezna i zapravo sama izabrati mjere, načine njihove primjene te dinamiku jer je zbog specifičnosti sustava moguće da kopiranje tuđeg modela implementacije ne poluči željene rezultate. $U$ tom smislu, potrebna su daljnja istraživanja koja će pružiti odgovore na ta otvorena pitanja. 


\section{LITERATURA}

Acemoglu, D., Johnson, S. , Robinson, J. (2004) „Institutions as the Fundamental Cause of the Long-Time Growth". U Handbook of Economic Growth. http://www.nber.org/papers/w10481.pdf

Acemoglu, D., Johnson, S., Robinson, J. (2005) „The Rise of Europe: Atlantic Trade, Institutuional Change and Economc Growth", The American Economic Review, (95), 3: p. 549-575.

Algan, Y., Cahuc, P. (2010) „Inherited trust and growth“, The American Economic Review, vol. 100, 5, p. 2060-2092

Barro, R. J. (1991) „Economic Growth in a Cross-Section of Countries“, Oxford Journals: Quarterly Journal of Economics, vol. 106, No. 2, p. 407-443

Bassanini, A., Scarpetta, S., Hemmings, P. (2001) „Economic growth: The role of Policies and Institutions, Panel data evidence from OECD countries", OECD working paper, http://www.oecd.org/dataoecd/29/29/1891403.pdf

Chong, A., Calderon, C. (2000) "Causality and Feedback Between Institutional Measures and Economic Growth“, Economics and Politics, vol. 12, No. 1., p. 69-81

Comin, D., Mestieri, M. (2016) „If Technology Has Arrived Everywhere, Why Has Income Diverge?", http://www.dartmouth.edu/ dcomin/files/CM_rev.pdf (22. 2. 2018.)

Dang, V. (2009) „Institutional Determinants of Investment in Transition Economies“, Brunel University, London, http://www.brunnel.ac.uk/9379/efwps/0933.pdf_(12. 11. 2017.)

David, T., Mach, A. (2006) „Institutions and Economic Growth - The Successful Experience of Switzerland (1870-1950)“, United Nations University, Research Paper No. 2006/101

Easterly, W. (2013) „The Tyranny of Experts: Economists, Dictators, and Forgotten Rights of the Poor“, Basic Books, New York

Fratzscher, M., Bussiere, M. (2004) „Financial openess andd growth: Short-run gain, long-run pain“, European Central Bank, Frankfurt am Main.

Goes, C. (2015) „Institutions and Growth: a GMM/IV Panel VAR Approach“, IMF Working Paper WP/15/174 Jackson, K. A. et al. (2001) „International Property Rights Indeks 2013 Report“, Property Rights Alliance, Washington Kaufmann, D., Kraay, A., Zoido-Lobaton, P. (1999) „Governance Matters", Policy Research Working Paper 2196, The World Bank, Washington.

Knack, S., Keefer, P. (1995) „Institutions and Economic Performance: Cross-Country Tests using Alternative Institutional Measures", Economics and Politics, Vol. 7, No. 3., 1995., p. 207-227

Mauro, P. (1995) „Corruption and Growth“, Oxford Journals: Quarterly Journal of Economics, vol. 110, No. 3, p.681-712

Meon, P.-G., Weill, L. (2003) „Does better governance foster efficiency? An aggregate fronrier analysis“, Universite Robert Schuman, Paris, 2003., http://www.springerlink.com/content/gjaupx85p35jptwp/ (7. 3. 2017.)

Pritchett, L. (1998) „Patterns of Economic Growth: Hills, Plateaus, Mountains and Plains“ The World Bank, http://elibrary.worldbank.org/content/workingpaper/10.1596/1813-9450-1947, (10. 12. 2017.)

Radošević, D. (2012) „Upravljanje kapitalnim računom Hrvatske i dužnička kriza Europske monetarne unije: preispitivanje", Ekonomski pregled, 63, 3-4, p. 128-161.

Rodrik, D., Subramanian, A., Trebbi, F. (2004) „Institutions rule: the primacy of institutions over geography and integration and economic development", National Bureau of Economic Research, Cambridge, WP 
V. Buterin, B. Olgić Draženović, P. Jakovac: Institucije kao determinanta ekonomskog rasta - primjer... Zbornik Veleučilišta u Rijeci, Vol 6 (2018), No. 1, pp. $217-234$

9305, http://www.nber.org/papers/w9305 (14. 12. 2017.)

Roy, K. C., Tisdell, C. A. (1998) "Good governance in sustainable development: the impact of institutions", International Journal of Social Economics, 25, 6-7-8, 1998, MCB University Press, p. 1310-1325.

Ulubasoblu, M., A., Doucouliagos, C. (2004) „Institutions and Economic Growth: a System Approach“, http://econpapers.repec.org/paper/ecmausm04/63.htm (11. 12. 2017.)

Vamvakidis, A. (2007) „External Debt and Economic Reform: Does a Pain Reliever Delay the Necessary

Treatment?", IMF Working Paper WP/07/50, Washington, http://www.imf.org/external/pubs/ft/wp/2007/wp0750.pdf (8. 12. 2017.)

Vijayaraghavan, M., Ward, W. A. (2001) „Institutions and Economic Growth: Empirical Evidence from a Cross-

National Analysis", Heritage Country Rankings 2012

IMF 2011

IPRI 2018

The World Bank 2009

http://www.heritage.org

www.hnb.hr;

www.hgk.hr;

www.dzs.hr 


\title{
INSTITUTIONS AS A DETERMINANT OF ECONOMIC GROWTH - THE CASE OF CROATIA AND SOME SELECTED EU MEMBERS ${ }^{4}$
}

\begin{abstract}
Economic growth and its causes have long been explored in economic science. More recently, the quality of institutions has been recognized as an important determinant of economic growth. It can be said that the quality of institutions is almost inseparable from the economic growth of modern economies. Using the indicators of institutional development, the authors have researched whether institutions had an impact on the economic growth of Croatian economy when compared to some selected EU members. The authors have found out that the institutions have had a marked impact on the growth, in particular where the Index of Economic Freedom and the International Property Rights Index have been analyzed. It is in these areas in particular that Croatia needs to make a significant institutional shift in order to stimulate institutional change. In addition, other formal institutions such as the degree of openness, the rule of law, but also the importance of encouraging the change of informal institutions should not be neglected, because the importance of informal institutions in Croatia is relatively high. The authors have concluded that a stimulating institutional change will trigger and lead to positive economic growth processes.
\end{abstract}

Key words: economic growth, institutions, institutional change, Croatia, selected EU members

\footnotetext{
1 PhD, Assistant Professor, Faculty of Economics, University of Rijeka, Ivana Filipovića 4, 51000 Rijeka, Croatia. E-mail: vesna.buterin@efri.hr

2 PhD, Assistant Professor, Faculty of Economics, University of Rijeka, Ivana Filipovića 4, 51000 Rijeka, Croatia. E-mail: bojana.olgic.drazenovic@efri.hr

3 PhD, Assistant Professor, Faculty of Economics, University of Rijeka, Ivana Filipovića 4, 51000 Rijeka, Croatia. E-mail:pavle.jakovac@efri.hr

4 Received: 15 January 2018; Accepted: 1 March 2018
} 
